\title{
Niching as a Macrostructural Procedure
}

\author{
Rufus H. Gouws, Department of Afrikaans and Dutch, University of \\ Stellenbosch, Stellenbosch, Republic of South Africa \\ (rhg@akad.sun.ac.za)
}

\begin{abstract}
Niching is a macrostructural procedure of textual condensation which results in different dictionary articles being clustered into one textblock as subarticles headed by sublemmata. This article offers an identification and critical discussion of different types of niching. Examples from dictionaries are used to examine problems which dictionary users experience as a result of the application of niching. The emphasis is on problems regarding the search route of users via the outer access structure of dictionaries. A distinction is made between single niching and multiple niching. Different aspects of multiple niching receive attention, e.g. the use of remote and exclusively remote multiple niching. The focus is also on an increased degree of textual condensation resulting from these procedures as well as problems in the domain of the access structure. Attention is drawn to the influence of the inclusion of homonym pairs on the application of multiple niching. Problems arising from an inconsistent application of multiple niching are identified and solutions are suggested for these problems in order to enhance the quality of the lexicographic practice. It is shown that a user-driven dictionary would rather opt for the application of procedures of single niching and first level nesting instead of multiple niching.
\end{abstract}

Keywords: EXCLUSIVELY REMOTE MULTIPLE NICHING, FIRST LEVEL NESTING, HETEROGENEOUS NICHING, HOMOGENEOUS NICHING, HYBRID NICHING, MULTIPLE NICHING, NESTING, NICHING, PARTIAL ARTICLE STRETCH, REMOTE NICHING, SINGLE NICHING, TEXTUAL CONDENSATION

Opsomming: Nisting as 'n makrostrukturele prosedure. Nisting is 'n makrostrukturele teksverdigtingsprosedure waardeur woordeboekartikels in een teksblok as subartikels met sublemmata gegroepeer word. Hierdie artikel bevat ' $n$ beskrywing en kritiese bespreking van verskillende tipes nisting. Aan die hand van woordeboekvoorbeelde word probleme wat gebruikers met die toepassing van verskillende nistingsmetodes kan hê, onder die loep geneem. Daar word veral gefokus op probleme wat nisting kan skep met betrekking tot die soekroete van gebruikers op die eksterne toegangstruktuur van woordeboeke. 'n Onderskeid word gemaak tussen enkelnisting en veelvuldige nisting. Verskillende aspekte van veelvuldige nisting word ondersoek, onder meer die gebruik van verwyderde en eksklusief verwyderde veelvuldige nisting. Die verhoogde graad van teksverdigting wat daardeur teweeggebring word asook die toegangstruktuurprobleme word bespreek. Aandag word ook gegee aan die invloed wat die opname van homoniempare op veelvuldige nisting het. Leemtes en inkonsekwenthede in die toepassing van veelvuldige nisting word bespreek en voorstelle word aan die hand gedoen ter verbetering van die huidige toepassing daarvan in die leksikografiepraktyk. Daar word aangedui dat 'n gebruikersgedrewe woordeboek

* This article is an expanded version of a paper read at the Eleventh International Symposium on Lexicography, University of Copenhagen, Copenhagen, 2-4 May 2002.

Lexikos 12 (AFRILEX-reeks/series 12: 2002): 133-158 
eerder van veelvuldige nisting moet afstand doen ten gunste van prosedures van enkelnisting en eerstevlaknesting.

Sleutelwoorde: EERSTEVLAKNESTING, EKSKLUSIEF VERWYDERDE NISTING, ENKELNISTING, GEDEELTELIKE ARTIKELREEKS, HETEROGENE NISTING, HIBRIDIESE NISTING, HOMOGENE NISTING, NESTING, NISTING, TEKSVERDIGTING, VEELVULDIGE NISTING, VERWYDERDE NISTING

\section{Introduction}

When the macrostructure of a dictionary is observed, the lexical items selected for inclusion as lemmata could be classified according to different sets of criteria, e.g. according to their form as items of the lexicon of the specific language and according to their presentation as macrostructural entries. With regard to their form, a distinction can be made between words, items smaller than words and multiword items, presented as lexical lemmata, sublexical lemmata and multilexical lemmata respectively (cf. Gouws 1991). As far as the presentation of lemmata is concerned, a well-established distinction exists, based on the occurrence of the lemmata as either main lemmata, participating in the vertical ordering of macrostructural elements, or sublemmata, participating in the horizontal ordering of macrostructural elements. Within the category of sublemmata a further distinction is made, i.e. between niched and nested sublemmata (cf. Hausmann and Wiegand 1989). These lemmata function as the guiding elements of niched and nested articles respectively. Procedures of niching and nesting are primarily performed as a space-saving endeavour. The presentation of lemmata in a cluster instead of a linear ordering has to be regarded as a form of textual condensation (cf. Wiegand 1998, Wolski 1989a). All procedures of niching and nesting do not display the same degree of textual condensation and when evaluating this type of macrostructural presentation one has to be aware of the genuine purpose of the specific dictionary and one should focus on the type of dictionary, its target users and the reference skills of those target users.

In this paper various aspects of niching will be discussed with the emphasis on procedures of multiple niching. Some implications of niching for the outer access structure of dictionaries will also receive attention.

\section{Niching and nesting}

Niched and nested lemmata deviate from the strict application of a linear macrostructural ordering due to the fact that access to the articles with the niched and nested lemmata as guiding elements is only possible when the search route goes via a basis lemma (cf. Wiegand 1989: 390), functioning as nich/nest entrance lemma (cf. Wolski 1989).

Niching (cf. Hausmann and Wiegand 1989: 336) is a strict alphabetical 
clustering of lemmata or articles which may or may not be semantically related, whereas nesting is a clustering of lemmata or articles which displays a deviation from the rules of strict alphabetical ordering. According to Wiegand (1989: 391), a nest is a cluster that contains at least one lemma that deviates from the alphabetical ordering. The alphabetical ordering that characterises niching applies on a cluster-internal and cluster-external level (cf. Gouws 2001). The lemmata occurring within the niche are ordered alphabetically and the niche fits into the alphabetical environment framed by the preceding and the following main lemmata.

Wiegand (1989: 391-392) mentions two ways in which nesting exhibits deviation from the strict alphabetical ordering. External deviation implies that the lemmata included in the nest do not fit into the alphabetical environment framed by the preceding and following main lemmata. In this regard nesting typically leads to a clustering of lemmata which alphabetically follows the basis lemma but at least one lemma in this cluster disturbs the alphabetical link with the following main lemma, cf. the following example from the Verklarende Afrikaanse Woordeboek (henceforth abbreviated as VAW):

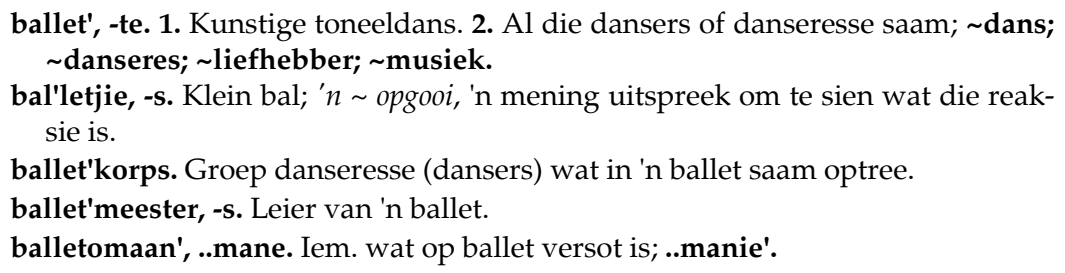

In a strict alphabetical ordering the sublemma balletliefhebber should have been ordered between the lemmata balletkorps and balletmeester and the sublemma balletmusiek should have been ordered after the lemma balletmeester. In isolation the cluster constituting this type of nest does not differ from an isolated cluster representing a niche because on a cluster-internal level the strict alphabetical ordering is maintained. Gouws (2001: 106) refers to this type of nesting as first level nesting.

Internal deviation prevails where the lemmata presented in the cluster do not adhere to a strict alphabetical ordering. This type of nesting (cf. Gouws 2001: 106) is known as second level nesting, cf. the following example from Nasionale Woordeboek:

re'gering (-e, -s) s.nw. 1. bestuur, bewind, veral uitoefening van die oppergesag; landsbestuur. Aan die - kom. 'n Demokratiese -. Die - aanvaar, neerlê. Onder die - van Willem II. 2. bepaalde kabinet, ministerie, party aan die bewind. Die van Hertzog. In die - sit. 'n Maatreël van die -. 3. owerheid, staat. regeringloos; regeringsamp, -amptenaar, -gebou, -koste, -pos, -vorm; regeringsaak, -stelsel (by 1); regeringsbeleid, -besluit, -blad, -hoof, -kringe, -man, -party, -tyd (by 2). 
In this example the first nested lemma (regeringloos) is a derivation whereas the other are compounds. Morphological differences within the nest motivate the use of a semi-colon to separate the derivation from the compounds. In the first group of compounds (up to regeringstelsel) the first sense of the main lemma prevails. This is indicated by the structural marker (by 1). In the second group of compounds the second sense of the main lemma prevails. Semantic reasons motivate the use of two distinct groups of lemmata representing the compounds. Within each one of the two groups of nested lemmata an internal alphabetical ordering has been maintained. However, due to morpho-semantic reasons the nest as such does not display an internal alphabetical ordering.

If the main characteristic feature of nesting is a deviation from the strict alphabetical ordering (cf. Wiegand 1989: 391), then first and second level nesting share a strong common ground which clearly distinguishes them from niching. However, Hausmann and Wiegand (1989: 336), argue that nesting stretches the rules of strict alphabetical ordering in order to exhibit morphosemantic relations between words, and according to Wiegand (1989: 390) a nest-internal deviation from the alphabetical ordering could be regarded as an attempt to separate sublemmata representing derivations and compounds. If these morpho-semantic motivations characterise nesting at best then second level nesting distinguishes itself from both first level nesting and niching. According to Hausmann and Wiegand (1989: 336), the lemmata in a niche may or may not be semantically related. Although the lemmata participating in a procedure of first level nesting usually show a semantic relation with the basis lemma the internal ordering is determined on alphabetical grounds. This then indicates a stronger relation with niching than with second level nesting. A better option would then be to work with first and second level niching where the occurrence of an external deviation from the strict alphabetical ordering represents second level niching.

Although space-saving reasons play an important role in the decision to accommodate lemmata in article clusters, the use of a sinuous lemma file can challenge the ground rules of ordering in a strict alphabetical dictionary. The adherence to morpho-semantic criteria in the ordering of lemmata results in a dictionary displaying a hybrid ordering system.

In this article the existing distinction between niching and nesting will not be investigated or questioned any further. However, the implications of a too strong alphabetical bias will be discussed and attention will also be given to problems arising from a hybrid macrostructural ordering system.

\section{Varying degrees of textual condensation ${ }^{1}$}

One of the characteristic features of a niche is that the lemmata and articles have been clustered into a single textblock, cf. the following example:

ballet', -te. 1. Kunstige toneeldans. 2. Al die dansers of danseresse saam; dans; danseres; liefhebber; musiek. 
A typical textblock is introduced by a guiding element, usually the basis lem$\mathrm{ma}$, which is a full lemma functioning in the niche entrance position. A niche displays a lesser degree of textual condensation if the sublemmata maintain their form as full lemmata. However, the degree of textual condensation is often increased by a procedure of phasing out to the left. A textblock containing a cluster of niched articles can be attached to the article of a main lemma but instead of having a sequence of full sublemmata in the niche, a procedure of phasing out to the left, followed by a further procedure of textual condensation, leads to more complex textual condensation. The mutual first component of the sublemmata is phased out to the left and stranded in the niche entrance position. There it does not function as a treatment unit but only as a guiding element to lead the user to the partial lemmata remaining in the niche. In the following example from the Elektroniese Verklarende Handwoordeboek van die Afrikaanse Taal (henceforth abbreviated as ElHAT), the sublemmata kleinkasboek, kleinkasboekhouer and kleinkashouer are the targets of a process of phasing out to the left. This results in the lemma external part kleinkas- positioned in the niche entrance and the partial lemmata boek, boekhouer and houer completing the niche (cf. Wolski 1989):

klein'kas (handel) Geld in hande vir daaglikse klein kontantuitgawes. kleinkas: boek, boekhouer, houer.

A higher degree of textual condensation can occur when the phasing out to the left goes beyond the borders of the attached cluster, resulting in the basis lemma functioning in a remote niche entrance to combine with each one of the partial lemmata in the niche individually as treatment units. This is illustrated by the following example from New Words/Nuwe Woorde:

heat $n .,(B r$. sl.) polisieondersoek; (sl.: pistool, rewolwer, skietding) yster, twa, rollie, $7 \mathrm{~mm}$; the $\sim$, (sl.: die polisie) die pote/honde/boere; put the $\sim$ on s.o. die wêreld vir iem. warm maak, druk op iem. uitoefen; take the $\sim$ for s.t., (Am. sl.) deurloop (of onder skoot/vuur kom) oor iets. $\sim$ death hittedood. $\sim$ engine hittemasjien, warmte-enjin. $\sim$ flash hitteflits (by kernontploffing). $\sim$ proof hittevas, =bestand. pump hittepomp. -seeking $a$. (attr.) hittegeleide (missiel); hittesensitiewe, warmtegevoelige (kamera). -sensitive hittesensitief, warmtegevoelig (materiaal, papier, selle, ens.). shield (teg.) hitteskerm.

In such a textblock, the retrieval of information demands a reconstruction of lemma signs and this reconstruction process exceeds the boundaries of the single article. Although it is more difficult to achieve a successful dictionary consultation procedure in a niche with partial lemmata, the user still has the advantage of a full lemma in the niche entrance position, albeit that the niched articles are separated from this niche entrance position. Still, the search route of the user from the basis lemma to the niched lemmata does not have to exceed the boundaries of a single textblock. 
A similar situation is seen when the cluster of unexplained compounds is attached to the end of the article of a full lemma. This niche presents a sinuous file of partial lemmata without either a full lemma or a lemma part representing the first component of the compounds in a niche entrance position in close proximity. Reconstructing the niched lemmata demands procedures exceeding article boundaries, cf. the following example from VAW ${ }^{2}$ :

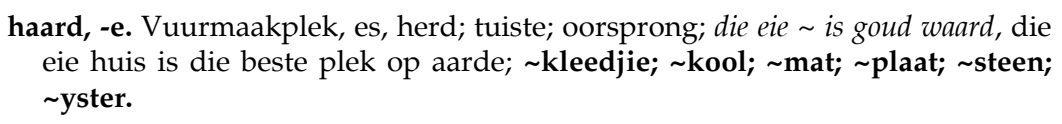

haard, -e. Vuurmaakplek, es, herd; tuiste; oorsprong; die eie is goud waard, die eie huis is die beste plek op aarde; kleedjie; kool; mat; plaat; steen; $\sim$ yster.

Yet again the user is assisted by the fact that the niche has been attached to an article with a full lemma as guiding element so that the search route to the lemmata in the niche can still proceed via the full lemma as basis lemma, albeit in a remote niche entrance position. An entry like haard in example (6) has a dual function. It is the lemma sign and treatment unit of an article but it also functions as lemma external part in a remote niche entrance position.

Textual condensation of a high degree also prevails where a textblock containing a niched cluster which has undergone phasing out to the left is not joined to the article of a full lemma but the lemma part in the niche entrance position is accommodated within the vertical ordering of the dictionary, cf. the following example from Tweetalige Woordeboek/Bilingual Dictionary (henceforth abbreviated as TW):

kin'der =: aard child nature. aftrek rebate (deduction) for children, tax abatement for children. kin'deragtig, kinderag'tig $=\boldsymbol{e}$ childish, babyish, infantile; petty, foolish, silly, puerile. kin'deragtigheid, kinderag'tigheid childishness, infantilism; foolishness, silliness, puerility, puerilism. arbeid child labour. $\sim$ arts children's specialist, $\mathrm{p}(\mathrm{a})$ ediatrist, $\mathrm{p}(\mathrm{a})$ ediatrician. baring child-bearing. bed child's bed, cot, crib; childbed. bedjie bassinet, cot, crib, child's bed. bedkoors childbed fever, puerperal fever. beskerming child (life) protection; vereniging vir $\sim$ child life protection society, children's aid society. bessie Halleria elliptica. beul bully (to children). bewaarplaas, =plek crèche, day-nursery; nursery school. ...

In the users' guidelines text of this dictionary, it is explained that the italics of the entry kinder = indicate that this entry follows a related previous lemma (kind). This adds to the degree of textual condensation and complicates the procedures of reconstruction and deconstruction the user has to apply in order to retrieve the needed information.

Due to orthographic conventions textblocks containing this kind of niched cluster could display additional textual condensation by presenting an extended lemma-external niche entrance (cf. Wiegand 2002). In the following example from the De Gruyter Wörterbuch Deutsch als Fremdsprache (henceforth abbreviated as DGWDF), the entries Eigen/eigen function as extended lemma- 
external niche entrance.

Eigen/eigen ['..] |-sinn, der $\langle\mathrm{o} . \mathrm{Pl}\rangle$ 'hartnäckiges Beharren auf seinem Tun, seiner Absicht, Meinung, verbunden mit einer Unzugänglichkeit für vernünftige Argumente'; ${ }^{\top}$ FELD I.2.1: sturer $\sim$; aus an einer Meinung festhalten; vgl. Trotz (1.1) ^ \ Sinn; -sinnig 〈Adj.; Steig. reg.〉 'mit, aus Eigensinn' /vorw. auf Personen bez./; ` FELD I.2.3: ein es Kind; auf etw. beharren; unser Kind war früher sehr $\sim \operatorname{Sinn} .$.

Neither of these lemma parts in the niche entrance can combine with both the partial lemmata included in the cluster. This type of phasing out to the left confronts the user, in this dictionary a learner of German, with extreme problems to achieve a successful dictionary consultation procedure. These problems are increased by the fact that the DGWDF does not employ the system of hyphenated entries to indicate that the element functioning in the extended niche entrance is only a lemma part. Only the entries presented as partial lemmata in the lemma niche have a hyphenated status.

These problems have been accounted for in a slightly more satisfactory way in TW. Although there is orthographic variation with regard to the first stem of the compounds functioning as niched lemmata, the default form is presented in the niche entrance and the deviation of this default model is indicated at the relevant occurrences. The lemma parts in the niche entrance position are presented as post-hyphenated entries (cf. Gouws 1989: 216), with the partial lemmata of the niche presented as pre-hyphenated entries. ${ }^{3}$ The following example illustrates the TW approach:

blou $=e, n$. (shade of) blue, blou $\sim,=e=e r=s t e, a$. blue; cyanotic; $\sim$ aniline analine blue; asbes, vid. blou-asbes; baba b. baby; bloed b. blood; die $\sim$ dam the sea; geen e duit werd nie not worth a fig (a brass farthing); hy het geen e duit nie he hasn't got a bean; $\sim$ van die koue blue with cold; $\sim$ maan, son blue moon, sun; Maandag black Monday; elke Maandag every now and then; sy het ' $n \sim$ Maandag by ons gekuier she stayed with us some short time; die B $N y l$ the B. Nile; iem. ' $n \sim$ oog slaan give s.o. a black eye; $\sim$ pas walking ticket (papers, orders); iem. die pas gee send s.o. packing; plekke, (also) bruises; ' $n \sim$ skeen kry be refused (by a girl); die B $\sim$ Trein the B. Train; $\sim$ walvis, vid. blouwalvis; wimpel b. ribbon (of the Atlantic); winde, vid. blouwinde; hy kan praat tot hy $\sim$ word he can talk till he is blue in the face. -aap, -apie vervet (monkey), blue monkey. blou'agtig $=e$, vid. blouerig. -apiestuipe: $d i t$ gee my die $\sim$ it gives me the creeps. -asbes crocidolite, $b$. asbestos. $\sim$ baadjie convict, prisoner with indeterminate sentence. $\mathbf{B} \sim$ baard Bluebeard. $\sim$ beer $b$. or glacier bear. $\sim$ bek $n$. tribulosis (in sheep)....

Although an entry like $B \sim$ baard in the penultimate line of this example is a highly condensed macrostructural item, the niche as a whole is subjected to a lesser degree of textual condensation. This does, however, raise another question in terms of the success of the niching. One of the decisions a lexicographer 
has to make as part of the planning of a dictionary and which has to be accounted for in the instruction book for the specific dictionary regards the access alphabet. Clear decisions should be taken to ensure a proper ordering of lemmata with orthographic differences, not only in terms of the alphabet letters used but also in terms of other orthographic conventions, e.g. the use of hyphens, capital letters, the umlaut, the circumflex, etc. (cf. Bergenholtz 1990: 22). Where the orthography of a word pair differs only in terms of the use of a capital versus a small letter the macrostructural ordering of these words as lemma signs should be influenced by this difference. The access alphabet of the specific dictionary should determine which form takes precedence. From a user-perspective, it adds to the textual condensation if the dictionary does not make provision for this kind of ordering. An arbitrary ordering or an ordering which merely ignores the difference is not acceptable. In this regard, the system prevailing in both the DGWDF and the TW is unacceptable. The successful utilisation of a procedure of niching demands that the first component, i.e. the component presented as lemma part in the lemma external niche entrance position, of all lemmata clustered into a niche must be fully identical in terms of orthography. Differences based on e.g. small versus capital letters and other orthographic conventions should be accounted for in the discussion of the access alphabet of the dictionary, and word pairs displaying such differences may not be included in the same niche.

\section{Single and multiple niching}

It has already been indicated that the pertinent difference between first level nesting and niching lies on the level of the adherence to or deviation from a consistent application of strict alphabetical ordering. In both these types of macrostructural ordering, the strict alphabetical principle is maintained on a cluster-internal level. Dictionaries in which sinuous lemma files prevail often limit the clustering procedures to a combination of niching and first level nesting. Second level nesting can be regarded as not only a higher degree of textual condensation but also as a more sophisticated lexicographic procedure which demands more comprehensive dictionary-using skills.

The decision to use a macrostructural ordering system which relies on sinuous lemma files should not be taken without proper consideration and an awareness of the needs and reference skills of the intended target user. However, once this decision has been taken, the dictionary plan should make provision for the best possible implementation of the system of clustering. Space saving has to be regarded as one of the most imperative reasons for the use of sinuous lemma files. This leads to the grouping of articles into single textblocks. Finding one's way in a cluster demands a cluster-internal ordering system which can ensure the user easy access to the desired guiding element of an article accommodated within a cluster. Niching implies the bringing together in one textblock of various articles (cf. Wiegand 1989: 388). 
In a dictionary, the focus on the user and his/her ability to retrieve the needed information from the presented data should never be subordinate to space-saving procedures. Lemma clustering should be done in a way which does not confront the user with an unrealistic challenge to reach the desired lemma sign. In this regard, the type of articles brought together in a niche or nest should co-determine the way in which the dictionary deals with its sinuous lemma files. Where the textblock presents clustered lemmata which function as the guiding elements of articles with a restricted treatment, e.g. a clustering of unexplained compounds and derivations, the textblock structure could be of a very simple nature, characterised by the application of strict horizontal ordering, cf. the following example from the VAW:
hand'doek, -e. Absorberende doek waaraan 'n mens jou hande en gesig afvee na dit gewas is; die ingooi, die stryd gewonne gee; goed; linne; rak; roller; stof.

A knowledge of the alphabet and a bit of lexicographic endurance will allow the user to reach the desired lemma without too many problems. Especially if the way in which lemmata are ordered in a niche is explained in the users' guidelines of the dictionary, the system of niching does not impair the outer access structure of the dictionary. The clustering in example (10) is an illustration of single niching, i.e. where the clustering of complex words with a mutual first component is restricted to a single niche attached to the article introduced by the basis lemma. The application of single niching is not confined to a clustering of unexplained compounds and derivations. Articles with a more comprehensive treatment can also be clustered by means of single niching.

Niching is a result of various textblocks containing full lemmata with their accompanying articles being condensed into one textblock, albeit not one article. Procedures of horizontal ordering, e.g. in examples (4), (5), (6) and (10), lead to a non-vertical ordering of the textblock-internal lemma file. This procedure is also known as textual grouping (cf. Bergenholtz, Tarp and Wiegand 1999: 1815).

Grouping and the application of a strict horizontal ordering can be an access impediment in a textblock where the clustered lemmata are guiding elements of articles with a more comprehensive treatment. In the planning phase of such a dictionary, the micro-architecture should be devised to allow a textblock structure which enhances rapid access to the clustered lemmata. This could probably lead to a textblock-internal ordering which eschews the principle of grouping in favour of a presentation of listing (cf. Hausmann and Wiegand 1989: 336), with each niched article commencing on a new line. Yet again, the specific nature of the data-presentation in these niched articles should determine the decision to apply a procedure of grouping or listing. However, whether grouping or listing applies does not change the status of the cluster as belonging to one textblock. Niching should ideally result in all the textblocks that are candidates for participation in the textual condensation process di- 
rected at a specific basis lemma combining into one textblock, in which a strict alphabetical ordering guides the user to the desired lemma sign. From a userperspective, such a niche can be accessed in an unproblematic way.

In his discussion of niching in the DGWDF, Wiegand 2002 indicates the problems a user experiences when the results of niching in a given dictionary stretch over numerous columns and even pages. He rightly concludes that this is the wrong position for the application of space-saving procedures. When these procedures of clustering in the DGWDF are observed, a different picture is exposed from the applications of niching so far described. In this dictionary, the macrostructure is characterised by niching but it happens quite often that there is only a relation of distant addressing (cf. Louw and Gouws 1996: 98) between a niche and the relevant basis lemma.

In the DGWDF, all articles selected for participation in textual condensation, by means of clustering directed at one basis lemma, are not necessarily accommodated in the same niche but frequently in a series of niches separated by articles not participating in the relevant clustering (cf. Stark 2001: 21). This is illustrated by the presentation of lemmata with Haus / haus as first component:

(11) Haus [haus], das; es, Häuser ['hoize]; vgl. Häuschen 1.1. 'ein- od. mehrstöckiges Gebäude, das zum Wohnen dient'; $>$ FELD I.15.1: ein hohes, modernes, baufälliges, neues, altes $\sim$; ein $\sim$ bauen, einrichten, beziehen, sanieren, verkaufen, umbauen, renovieren, abreißen; ein besitzen; das steht unter Denkmalschutz; von $\sim z u \sim$ gehen 1.2. 〈o.Pl.; vorw. o.Art.; + Präp. $\rangle$ /meint den Bereich, in dem jmd. (ständig) wohnt/: jmdn. aus dem jagen; ...

Haus/haus ['..]|-arbeit, die 1. 〈o.Pl.〉 'im Haushalt (1) anfallende Arbeiten wie Waschen, Kochen u.Ä.': nach dem Dienst ist noch allerlei $\sim$ zu erledigen; sie schafft die nicht mehr 2. '(umfangreiche) schriftliche Hausaufgabe': eine in Biologie, Geschichte schreiben müssen * A Arbeit; -aufgabe, die 〈oft im Pl.〉 'dem Schüler vom Lehrer aufgetragene Aufgabe, die zu Hause erledigt werden soll': $\sim n$ aufgeben, aufhaben; die $\sim n$ erledigen, machen $\star \rtimes$ gegeben; -backen 〈Adj.; Steig. reg., ungebr.〉 'bieder, reizlos und etwas langweilig wirkend' /auf Personen, Denkweise bez./: jmd. hat e Ansichten; seine e Kleidung; sich kleiden ...

Häuschen ['hoisç̧n], das; s, ; vgl. Haus 'kleines Haus': wir haben ein am See * Haus $^{*}$ umg. /jmd./ aus dem $\sim$ geraten ...

hausen [hauzn] 〈reg. Vb.; hat〉 1. /jmd./ irgendwo 1.1. 'unter schlechten Bedingungen irgendwo dürftig wohnen'; $>$ FELD V.2.2: in Baracken (müssen) 1.2. ...

Haus/haus [haus..]|-frau, die 'den eigenen Haushalt führende (und nicht berufstätige) Frau': sie is (nur) , ist und Mutter * Frau; -halt, der; $\sim$ s/auch

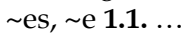

Haus halten (er hält Haus), hielt Haus, hat Haus gehalten /jmd./ mit etw. 'mit etw. sparsam umgehen' ...

Haus/haus |-herr, der veraltend 'der Familienvater (als Gastgeber)': der begrüßte die Gäste, schenkte den Wein ein * $>$ Herr; -hoch ...

häuslich ['hois...] 〈Adj.〉1. 〈o. Steig.; nur attr.〉'das Zuhause, die Familie, den Haushalt (1.2) betreffend': die en Verhältnisse von jmdm. (nicht) kennen ... 
Haus [haus..]|-nummer, die 'eine der laufenden Nummern, mit denen die Häuser einer Straße bezeichnet sind': bei der Adresse Straße und angeben * > Nummer; -schuh, der 〈vorw. Pl.〉 'bequemer, aus weichem Material gefertigter Schuh, der nur in der Wohnung getragen wird': e an-, ausziehen * $>$ Schuh; -segen, der * umg. scherzh. bei jmdm. hängt der $\sim$ schief ('in jmds. Ehe gibt es aus einem bestimmten Anlass (längeren) Streit, herrscht gereizte Stimmung'); -suchung [zuç..], die; , en 'polizeiliche Durchsuchung einer Wohnung, eines Hauses zur Aufkläring einer Straftat': bei jmdm. eine durchführen; die hat nichts ergeben * $>$ suchen; -tier, das 'vom Menschen bes. zur wirtschaftlichen Nutzung gehaltenes Tier'; ${ }^{\top}$ FELD II.3.1: die Katze ist ein ; Kühe, Pferde, Schafe, Hunde sind $\sim e * \pi$ Tier; -wirt, der 'jmd., der Eigentümer eines Hauses ist, in diesem Haus wohnt und die anderen Wohnungen des Hauses vermietet hat': der lässt unsere Wohnung sanieren, hat die Miete erhöht $\times$ Wirt

In this partial article stretch in example (11), Haus is presented as a main lemma and the guiding element of an article displaying a full treatment. The next guiding element presented in the vertical ordering of the macrostructure of the DGWDF is the extended lemma-external niche entrance Haus/haus. These lemma parts have been phased out to the left and introduce a cluster in which the partial lemmata -arbeit, -aufgabe and -backen head the niched articles. This cluster of grouped lemmata is followed by two vertically ordered main lemmata, i.e. Häuschen and hausen, preceding a next cluster with Haus/haus as phased out lemma parts in the entrance position of a new niche, which contains the sublemmata -frau, -halt and -halten. This niche is followed consecutively by the main lemma Haus halten, by another niche featuring Haus/haus in the entrance position and the partial lemmata -herr and -hoch in the cluster, before häuslich, as a new main lemma, interrupts the niching. The treatment of sublemmata with Haus as first component is concluded with the presentation of Haus as lemma-external niche entrance and the cluster of articles headed by the partial lemmata-nummer,-schuh,-segen,-suchung, -tier and -wirt.

The partial article stretch which starts with the textblock introduced by the lemma sign Haus and ends with the final article, headed by the grouped partial lemma sign -wirt, in the condensed text block introduced by the lemma-external niche entrance Haus is constituted by different textblocks. As a partial article stretch it is therefore not an example of textual grouping (cf. Bergenholtz, Tarp and Wiegand 1999: 1815) neither is it a functional article stretch (cf. Wiegand 2002).

This partial article stretch contains various niched articles with either Haus or haus as first component. These niched articles display a semantic and a morphological relation with both the basis lemma, i.e. the word Haus, and the other main lemmata in this particular article stretch, i.e. the complex forms Häuschen, hausen, Haus halten and häuslich. The reasons why these complex forms have been presented as main and not as niched lemmata are not made known to the user. A consistent application of a traditional system of clustering could have rendered all the niched articles and the main lemmata in this partial article 
stretch into one text block - ignoring for the moment the orthographic differences regarding the initial capital/small letter of the first component. Instead, the lexicographer has opted not to condense all the lemmata with Haus/haus as first component into one cluster but rather to present some of them as main lemmata and some grouped into different clusters. Such hybrid niching does not enhance the quality of the outer access structure.

In this partial article stretch from the DGWDF, the lexicographer repeatedly applies the procedure of niching to render a presentation of multiple niching, i.e. niching in one partial article stretch, characterised by the repetitive occurrence of niches with the same lemma part operating in the niche-external entrance position. The partial article stretch in example (11) contains no less than four niches resulting from a procedure of multiple niching.

The biscopal bilingual dictionary Groot Woordeboek/Major Dictionary (henceforth abbreviated as GW), with Afrikaans and English as treated language pair, utilises a system of niching comparable to that of the DGWDF. In the GW, the application of single niching which leads to a clustering of articles grouped into one text block with the basis lemma functioning, through a textual condensation process of phasing out to the left, as a remote niche entrance can be regarded as the default pattern, cf. the following example:

pup'pet, speelpop, handpop, draadpop, marionet; strooipop; werktuig, speelbal, figurant; government, marionetteregering; -man, marionetspeler; $\sim$ play, poppespel; ry, poppespel; skynvertoon; poppekastery; -show, poppekas, poppespel, marionet(te)spel; state, vasalstaat, popstaat; ministaat; r-valve, stootklep.

This clustering adheres to the criteria for single niching. On both the internal and the external level a strict alphabetical ordering is maintained. The grouping of articles gives the user access to the niched lemmata via the main lemma which functions as basis and as niche entrance lemma. This niching does not confront the experienced user with too many problems when retrieving the desired information from the GW. However, this is not the only way in which niching is performed in the GW. This dictionary frequently indulges in the application of procedures of multiple niching, motivated by an exaggerated adherence to the alphabetical approach. By doing so it stretches the limits of article clustering to domains where the target user struggles to find lemmata included in the article niches.

\section{Multiple niching in partial article stretches which include semantical- ly related main lemmata}

As is the case in the DGWDF's treatment of niched articles with Haus/haus as first component, the GW also displays partial article stretches which include repetitive niching of complex words with the same first component as well as 
main lemmata heading non-niched articles. Quite often all the lemmata included in such partial article stretches are semantically related because the main lemmata and the sublemmata share mutual components. In these partial article stretches, the niches resulting from a procedure of multiple niching are not interrupted by unrelated main lemmata, cf. the following example:

soft, (n) papbroek, stumper; (a, adv) sag (saf); mal; ... ball, sagtebal; -boiled, sag gekook; -brimmed hat, bolhoed(jie), dotjie; cover, slap band; ... ; ener, versagter, leniger; versagmiddel.

soft'ening, (n) verweking, versagting; ontharding (water); (a) versagtend; of the BRAIN, harsingverweking; UP, makmakery.

soft: $\sim$ furnishings, gordynstowwe; meubelstowwe; goods, wolstowwe, ...; $\sim$ sore, sagte (veneriese) sweer; -spoken, vriendelik, sag.

soft spot, teer plek, swak; attack someone's $\sim$, iem. in sy swak tas; have $a \sim$ for women, 'n swak hê vir vroue.

soft: steel, weekstaal; talk, mooipraatjies; touch, ligte aanslag; $\ldots$; water, sagte water; -wood, greinhout; naaldhout; jonghout; $\sim \mathbf{y}$, (..ties), papbroek, stumper, sul; teerhartige, goeierd.

This partial article stretch is the target of textual condensation by means of, among other methods, niching. However, instead of using the main lemma soft as a basis lemma giving access to all the niched articles, the lexicographer has opted for a different approach. The micro-architecture of the articles in the GW allows that an article niche can be attached to the article of a main lemma to form one textblock, e.g.:

$$
\begin{aligned}
& \text { soft, (n) papbroek, stumper; (a, adv) sag (saf); mal; ... ball, sagtebal; -boiled, } \\
& \text { sag gekook; -brimmed hat, bolhoed(jie), dotjie; cover, slap band; ... ; } \\
& \text { ener, versagter, leniger; versagmiddel. }
\end{aligned}
$$

The macrostructural elements in this niche (starting with ball) are not presented as full lemmata but only as partial lemmata. These pre-hyphenated entries are not the treatment units. Each partial lemma contains the second component of the relevant treatment unit and this component is preceded by a hyphen functioning as place-keeping symbol, substituting the element given in the remote niche entrance, here the lemma part soft. The full treatment units can only be identified through a process of textual reconstruction via the basis lemma as search route. In this regard the structure of this niche and the procedures to reconstruct the treatment units do not differ from those applicable in clusters resulting from single niching, e.g. example (12), the cluster introduced by puppet as basis lemma.

The given partial article stretch in example (13) contains two other niches in which complex forms with soft as first component have been clustered:

\footnotetext{
soft: furnishings, gordynstowwe; meubelstowwe; goods, wolstowwe, ...; $\sim$ sore, sagte (veneriese) sweer; $\sim$-spoken, vriendelik, sag.
} 
soft spot, teer plek, swak; attack someone's $\sim$, iem. in sy swak tas; have $a \sim$ for women, 'n swak hê vir vroue.

soft: steel, weekstaal; talk, mooipraatjies; touch, ligte aanslag; $\ldots$; water, sagte water; -wood, greinhout; naaldhout; jonghout; $\sim \mathbf{y}$, (..ties), papbroek, stumper, sul; teerhartige, goeierd.

These niches constitute separate textblocks and they are not attached to the article or textblock of a basis lemma. The articles included in these niches participated in the process of textual condensation that have clustered certain complex forms into the textblock introduced by the basis lemma. However, the alphabetic bias prevailing in this dictionary has ensured the establishment of additional niches, separated from the textblock of the basis lemma by other textblocks featuring main lemmata and their treatment. The niches in example (15) are the result of multiple niching and more specifically a process of remote multiple niching, i.e. the formation of niches in textblocks separated from the textblock which accommodates the basis lemma by one or more textblocks headed by their own main lemmata. The further a niche is removed from the basis lemma the more difficult it is for the user to perform a successful dictionary consultation procedure in terms of rapidly accessing the textblock which contains the relevant niched lemmata.

From both a space-saving perspective, the dominant reason for lemma clustering, and a semantic perspective there is no reason why softening and softspot should have been given main lemma status. A consistent application of textual condensation by means of lemma clustering could have accommodated these two lemmata along with all those included in the three niches presented in this partial article stretch in one amalgamated textblock. The inclusion of softening and softspot as main lemmata could have been motivated by their usage frequency. This, however, is not of importance in the present discussion. If, for whatever reason, their inclusion as main lemmata is justifiable, the question remains how the other complex words with soft as first component should have been ordered as sublemmata. They could easily have been included in one textblock attached to the main lemma soft, functioning as basis lemma and lemma part in lemma-external remote cluster entrance. An internal alphabetical ordering could easily have been maintained in this cluster.

In the vertical ordering of lemmata the main lemma soft would then have been followed by the main lemmata softening and softspot. By doing so the lexicographer would have deviated from a strict alphabetical ordering because the cluster of lemmata does not adhere to an external alphabetical ordering. According to a strict alphabetical ordering, both the lemmata softening and softspot should have preceded some of the lemmata in the cluster. This presentation would have been an example of first level nesting.

Niching, by definition, does not take cognisance of morpho-semantic relations but only adheres to a strict alphabetical ordering. When niching leads to the clustering of all the sublemmata with a mutual first component into one text block, the users of the dictionary get accustomed to a system where one main lemma gives access to all the sublemmata relevant to the basis lemma. Al- 
though this kind of textual condensation, especially in a niche with many subarticles, can create some retrieval difficulties for the user, the systematic application of this type of clustering can lead to a relative easy access to the desired lemma signs. Grouping in an article cluster leads to a sinuous lemma file where each article does not start on a new line. In a niched ordering where the cluster contains many articles, the application of a system of listing or non-grouping where the micro-architecture allows each sublemma to be positioned at the beginning of a new line, enhances user-friendliness and an easier access to the lemma signs.

Whether a system of grouped or listed sublemmata is employed the essence of niching should be regarded as the clustering of lemmata into a single text block. Multiple niching confronts the user with a more problematic information retrieval challenge due to the more complicated external access route. The basis of multiple niching is an ardent alphabetic bias. This bias often prevails at the cost of user-friendliness. Multiple niching leads to the formation of more than one article cluster. In an application of first level nesting the same sublemmata would have been clustered into one textblock, attached to the article of one basis lemma. However, due to multiple niching they are accommodated in different niches, constituting different textblocks. These niched textblocks are interrupted by other textblocks presenting non-clustered main lemmata. From an access-structure perspective, multiple niching increases the difficulties users experience in their attempt to reach a desired lemma sign. This applies even if the main lemmata heading the interrupting textblocks are semantically related to the niched lemmata. The search route is no longer directed only at one cluster but the user has to go through the first cluster and then has to cross textblock barriers, negotiate the articles of main lemmata to which no clusters are attached and only then move into further niched clusters in the hope of finding the desired lemma.

The application of multiple niching leads to additional problems for the dictionary user. When a dictionary employs procedures of multiple niching it necessarily also has to use single niching to establish the default niches. Such a system relies on the use of different types of niches. In the default niche, the article of the lemma puppet (cf. example (12)), the user can find all the subarticles directed at one basis lemma accommodated in one textblock. Contrary to this, the occurrence of multiple niching spreads these subarticles over various textblocks. This hybrid method of niching adds to the problems the typical target user of a dictionary experiences during a dictionary consultation procedure. The combination of single niching and first level nesting will ensure that a user can consistently find all the subarticles clustered into one textblock.

\section{Multiple niching in partial article stretches which include semanti- cally unrelated main lemmata}

Niched articles resulting from the application of multiple niching are more easily accessible in a partial article stretch where all the lemmata are semantically related (cf. example (13)). When the niches are interrupted by lemmata 
which do not display a semantic relation with the basis lemma of the first in the series of multiple niches, access to the subarticles participating in a procedure of multiple niching is further impeded, cf. the treatment of complex words with sea as first component in the GW:

sea, see; deining, golf, branding; oorvloed; menigte; $A T \sim$, op see; ...; $a \sim$ of TROUBLES, 'n oseaan van leed; acorn, eendemossel; -action, seegeveg; $\sim$ aerodrome, $\sim$ airport, ...; -kale, seekool; -king, seekoning; -kit, seemansuitrusting. seal1, (n) seeleeu, rob; (v) robbe vang.

seal2$^{2}$, (n) seël; stempel; beseëling; stempelafdruk; ykmerk; lak; the GREAT S , die Rykseël; ...

sea: lace, seewier; lamprey, seeprik; ... ; lawyer, vitterige persoon; korrelkop; -legs, seebene; find (get) one's -legs, jou seebene kry, leer om jou maklik op die dek te beweeg.

seal'er1', robbejagter; robbeskip.

seal'er ${ }^{2}$, verseëlaar; deklaag.

sea'-letter, seebrief.

sea'-level, seevlak, seespieël; $A B O V E \sim$, bokant die seespieël (seevlak); $A T \sim$, by die seevlak (seespieël).

seal'-fishery, robbevissery, robbevangs.

Seal Island, Seal Island.

sea: life, seelewe; -line, horison, kim; kus; lang vislyn.

seal'ing1, robbejag.

seal'ing ${ }^{2}$, bekragtiging, bevestiging; digting; agent, digtingsmiddel; coat, deklaag; afdiglaag; ring, digtingsring; tree, kiaat (Pterocarpus angolensis).

seal'ing vessel, robbevaarder.

seal'ing-wax, lak.

sea: -lion, seeleeu; S Lord, lid van die admiraliteit in Engeland.

seal'-ring, seëlring.

seal: -rookery, robbekolonie; skin, robbevel.

seam, (n) soom, naat; aar, laag (kole); rimpel; ...

sea: $\sim$ man, seeman, matroos; seevaarder, varensgesel; manship, seemanskap, stuurmanskap; -mark, seebaken; men's institute, seemanshuis; -mew, seemeeu; mile, seemyl; mist, seenewel; seemis.

sea'mer, naatbouler.

seam: bowler, naatbouler; -bowling, naatboul; -bowling attack, naat(boul)aanval; -lap, naatrand; less, sonder naat, naatloos.

sea' monster, seemonster.

seam: -presser, parsyster; stress, (-es), naaister; -weld, naatsweislas; ...; y, vol nate; ...

sé'ance, sitting, séance.

sea: needle, geep; -nymph, seenimf; -onion, seeajuin; ...; quake, seebewing.

sear1, (n) tuimelaar (geweer).

sear $^{2}$, (v) brand, verskroei, uitbrand, toeskroei, digskroei; verhard; a wound, 'n wond toeskroei; (a) droog, dor.

search, (n) ondersoek; soekery, soek; ...; able, te ondersoek; er, soeker; deur- 
soeker, huissoeker; visenteeryster; botterboor; visenteermes; sondeernaald, peilstif; ing, (n) ondersoek; deursoeking; (a) deurdringend, ondersoekend, deurvorsend, grondig; noukeurig, diepgaande; ... ; -warrant, visenteerbrief, lasbrief vir huissoeking.

sea' reed, helmgras.

sear'ing-iron, brandyster.

sea: -risk, seerisiko; rover, seeskuimer, roofskip; swerwer op see; -salt, seesout; -sand, seesand; ...; sick, seesiek; sickness, seesiekte.

sea'side, strand; seekant; $A T$ the $\sim$, aan die strand; GO to the $\sim$, strand toe gaan; $\sim$ bungalow, strandhuis; cottage, strandhuisie; resort, strandplek, strandoord; $\sim$ wear, stranddrag.

sea: slug, seeslak; tripang, seekomkommer; snail, seeslak; snake, seeslang. seas'on, (n) seisoen, jaargety; geskikte tyd; tydperk; bronstyd; ... ; MORTAR, kalk insuur; oneself to hard WORK, jou aan harde werk gewoond maak; able, geskik, geleë, tydig; aktueel; passend by die seisoen.

seas'onal, seisoen $(s)=$, jaargetye $=$, seisoenaal, binneseisoens; $\sim$ greetings, Kers $=$ en Nuwejaarsgroete; valve, weerklep, seisoensklep; $\sim$ industry, seisoenbedryf; variation, jaargetyeverskil; worker, seisoenwerker.

seas'oned, gekruie, gesout, gepeper; beleë, droog (hout); food, gekruide kos; $\sim$ iron, getemperde yster; $\sim$ soldiers, geharde soldate; $\sim$ traveller, deurwinterde reisiger; $\sim$ wood, gedroogde (beleë) hout.

seas'on: ing, toebereiding, klaarmaak; kruiesous, smaakmiddel, kruisel; geursel; ontvarsing; kruidery; droging (hout); less, sonder jaargetye; -ticket, seisoenkaartjie.

sea' spray, bruiswater, seeskuim, brandersproei.

seat, (n) sitplek; stoel; gestoelte; sitting; setel; toneel; buiteplaas; ...

sea' tangle, seewier.

seat: back, rugleuning; belt, sitplekgordel; veiligheidsgordel.

sea term, seemansterm; vlootterm; inology, vlootterminologie, seeterme, seeterminologie.

seat'ing, sitplek; onderstuk; fundasie; accommodation, sitplek; plaasruimte.

sea: -toad, seeduiwel; -tossed, deur die see geslinger; $\sim$ training, seeopleiding; trout, seeforel; $\sim$ trumpet, trompetskulp; turtle, seeskilpad; ...; $\sim$ worthy, seewaardig; -wrack, seegras.

The process of textual condensation to cluster complex words with sea as first component leads to multiple niching. The given partial article stretch, example (16), contains the article with sea as main lemma with a niche attached to this article and no less than eight niches with sea as lemma-external lemma part in the niche entrance position, constituting a procedure of remote multiple niching. A number of main lemmata included in this partial article stretch show a semantic relatedness with sea. Besides the sea- and sea-related lemmata this partial article stretch also contains a variety of lemmata which are semantically unrelated to the main lemma sea. This partial article stretch also contains other examples of niching and multiple niching. The ordering of all the lemmata in this partial article stretch is only determined by the application of a strict alphabetical principle. 
This strict alphabetical ordering is, however, not user-friendly (cf. Stark 2001: 21). The user looking for, say, seasick in the GW goes to the article of the lemma sea and the attached niche where the desired form is not found. The following textblocks in the partial article stretch contain lemmata unrelated to sea and the user easily deduces that seasick has not been included in the macrostructure of this dictionary. If the user does look a bit further he/she may notice some other niches with sea-words and he/she could eventually, with some luck and many problems, reach the lemma seasick.

One real problem experienced in struggling through a partial article stretch like this is that the user never knows for sure whether a specific niche, attached to the article of a basis lemma, is the only niche accommodating complex words with the form represented by the basis lemma as first component or whether there are some other relevant alphabetically ordered niches further down the article stretch. Having reached an article cluster which presents one of the multiple niches for a given first component, the user is still at a lost and does not know whether any other niches prevail. This enhances user-frustration.

The clustering of sea-lemmata could have looked like this:

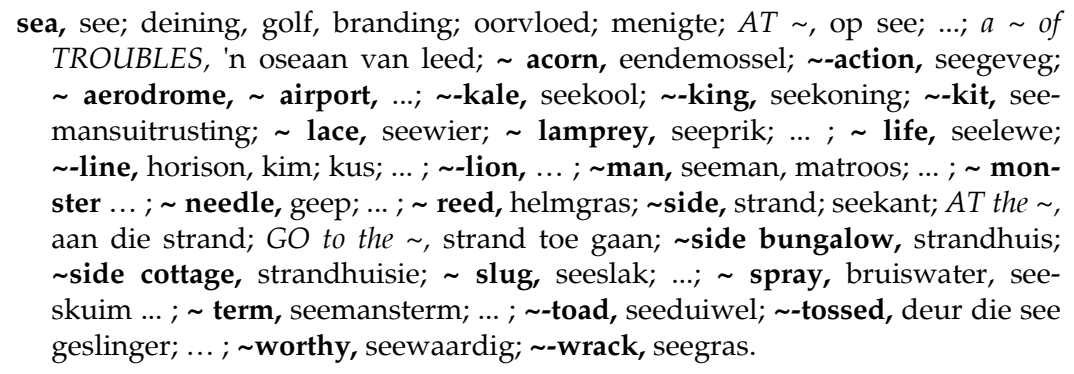

In the partial article stretch from the GW, example (16), similar changes could also have been made to the niching of words with seal ${ }^{1}$, seam and season. In all these clusters the use of a lesser degree of textual condensation regarding the lemma sign, i.e. refraining from place-keeping symbols and the use of partial lemmata, as well as the use of a system of listing could have added to the userfriendliness of this dictionary. This will, however, not be discussed in the present article.

Although the proposed clustering of sea-words would have resulted in a lengthy textblock with a relative high degree of textual condensation there would only have been one clear search route in the outer access structure guiding the user to the relevant lemma sign.

The suggested textblock for the treatment of sea-words deviates from the external alphabetical ordering and represents an application of first level nesting. As Gouws (2001: 108) has indicated, multiple niching confronts the dictionary with many more problems than either first level nesting or single niching. 
Both these procedures are much more user-friendly than multiple niching. Especially when multiple niching results in a partial article stretch where the niches are interrupted by main lemmata showing no semantic relation to the basis lemma or the lemmata participating in the clustering, users can easily loose their way on the search route of the outer access structure. For this reason the lexicographer preparing a user-driven dictionary will do well to avoid multiple niching.

\section{Exclusively remote multiple niching}

The following partial article stretch comes from the GW:

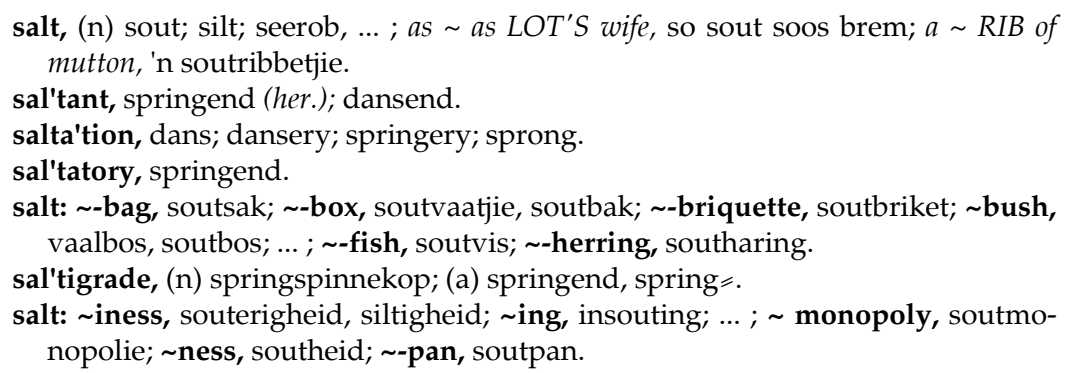

The textblock in which the article of the lemma sign salt appears has no niche attached to it. However, the given partial article stretch contains two niches accommodating complex words with salt as first component. Both these niches function as separate textblocks introduced by a lemma part in a lemma-external niche entrance position. This is yet another example of multiple niching and more specifically remote multiple niching. In partial article stretches like the one presented as example (13), remote multiple niching complemented niching attached to the article carrying the basis lemma. Contrary to this, example (18) illustrates the result of exclusively remote multiple niching, i.e. when none of the niches participating in a given procedure of multiple niching are attached to the article of the basis lemma.

Being familiar with niching and the use of the default niched article in the GW, the user starts the search route at the basis lemma and then works towards the attached niche. Having found no niche attached to the article of the lemma sign salt, the user can easily deduce that a word like saltmonopoly has not been included in the dictionary. Exclusively remote multiple niching can be regarded as an additional impediment in the outer access structure of a dictionary.

\section{Homonymy and multiple niching}

In dictionaries, homonyms are usually entered as separate macrostructural entries identified as such by superscript numbers immediately preceding or 
following the lemma sign, cf. the following example from the ElHAT:

grif ${ }^{1}$ b.nw. en bw. (deftig) Vlug, geredelik, vaardig; grifweg: Hy is nie juis grif van begrip nie. Grif op 'n vraag antwoord. Iets grif erken.

grif ${ }^{2}$ ww. (gegrif) 1 Met 'n stif kras, skryf, aanbring: Letters in 'n klip grif. Gegrifte tekens. 2 (fig.) Blywend, onuitwisbaar aanbring asof met 'n stif gekras: Dit staan in my geheue gegrif.

In a dictionary where procedures of niching prevail, each member of a homonym pair which is included as a vertically ordered main lemma could, where applicable, function as basis lemma for a niche with the niche attached to the same textblock, or even as lemma part in lemma-external niche entrance.

Afrikaans has three lexical items bak and they should be entered as three separate treatment units in a dictionary, cf. the following example from the ElHAT:

bak $^{1} \square$ s.nw. (-ke) 1 (Oop) kis waarin iets bewaar kan word: ' $n$ Bak vir meel, hout, steenkool. 2 Deel van wa, kar, motor, ens. wat op die onderstel rus. 3 Houer vir vloeistof: ' $n$ Bak met water. Drink-, suip-, doopbak. 4 Hoeveelheid wat in 'n bak gaan: ' $n$ Bak water, meel. $5 \mathrm{Hol}$ kant van 'n kromming: Die plate staan met ' $n$ bak. UITDR.: In die bak raak, agter raak. Iemand in die bak sit (nie alg.), hom oortref. $\square$ b.nw. en bw. Soos 'n bak: Sy bene, ore staan bak. Die hande bak hou.

bak ${ }^{2}$ ww. (bakkende; gebak) 1 Gaarmaak deur hitte: Eiers in die pan bak. Gebakte eiers. 2 Gaar word; warm kry: In die son sit en bak. 3 Hard (laat) word deur hitte: Stene bak. 4 Hitte afgee: Die son bak op die stoep. In die bakkende son. $\nabla$ Die son bak blink (M.M. Walters). UITDR.: Mooi broodjies bak - sien onder BROOD. Bak en brou, knoei. bak: $\sim$ dag, hoender, huis, kis, $\sim$ mengsel, $\sim$ skottel, $\sim$ trog.

bak $^{3}$ b.nw. en bw. (geselst.) Piekfyn, uitstekend: 'n Bak kêrel. Dit gaan vandag net bak. Vgl. BAKGAT.

ba'ka·tel' (-le) 1 Nietigheid: Waarom al die lawaai - die hele saak is net ' $n$ bakatel. 2 Sien BAGATEL. [F. bagatelle kleinigheid]

The article of the second lemma sign bak has an attached article cluster. This cluster features a strict internal alphabetical ordering of lemmata but introduces a deviation from the strict external alphabetical ordering. The next main lemma, i.e. $b a k^{3}$ representing the last member of the homonym paradigm, and the following main lemma (bakatel) should, in an application of strict alphabetical ordering, have been ordered prior to all the lemmata included in the article cluster. The fact that clustering in the ElHAT is not restricted to niching but that allowance is also made for first level nesting leads to a situation where a niche could be attached to the article of the lemma representing any member of a homonym paradigm. The user is given the advantage of finding a clustered lemma by progressing via a basis lemma which displays a semantic relation with the first stem of the complex lexical item represented by the clustered lemma. This is user-friendly lexicography. 
Where only niching is employed instead of both niching and first level nesting, clustering may not be performed in the articles of the non-final members of a homonym paradigm because it would lead to a deviation from the external alphabetical ordering. In a dictionary like the GW, the articles of these non-final members of a homonym paradigm are consistently excluded from niching procedures, $\mathrm{cf}$. the following example:

roei $^{1}$, (s) (-e), tail of a comet; lattice; mullion.

roei $^{2}$, (w) (ge-), row; pull (oars); bank, rowing-bench; thwart; boot, rowingboat; dol, rowlock; er, (-s), rower; oarsman, waterman; sculler; oar; klamp, rowlock; klub, boating (rowing) club; kuns, oarsmanship; watermanship; mik, rowlock; pen, thole; plank, surf board; plankry, surfing; $\sim$ riem, oar; spaan, (..spane), oar, scull; paddle; sport, rowing. roei'ster, comet.

The alphabetical bias allows the niche to be attached to the article of the lemma sign roei $i^{2}$ but no niche may be attached to the article of the lemma sign roei ${ }^{1}$. Instead, a separate main lemma roeister is included. This article could have been attached to that of the lemma sign roei ${ }^{1}$ if a procedure of first level nesting had been permitted.

When only niching instead of both niching and first level nesting as a form of external textual condensation (cf. Wiegand 1998) is utilised, the adherence to a strict alphabetical ordering compels the lexicographer to employ procedures of multiple niching to lemmatise and treat complex lexical items with a first component which is a stem variant of a lexical item functioning in a homonymous relation with another lexical item, with both these lexical items included as main lemmata. This is illustrated by the next example from the GW:

roes $^{1}$, (s) rust, blight, brand (in corn); hy IS ' $n \sim$, he is a wastrel; ' $n \sim$ in iem. se $S A K$, a drain on one's pocket; (w) (ge-), rust, corrode; get rusty; ou LIEFDE nie, true love never grows old; my REKENKUNDE is al ' $n$ bietjie ge , my arithmetic is a bit rusty.

roes $^{2}$, (s) intoxication bout, drunken fit; ecstasy, frenzy; flush (of victory); sy UITSLAAP, sleep off the effects of one's debauch; in die van VRYHEID, in the intoxication of liberty.

roes: agtig, (-e), rusty; bruin, rust-brown; dopluis, rusty scale.

roe'semoes, confusion, disorder, tumult, bustle; see also geroesemoes.

roe'serig, (-e), rusty; heid, rustiness.

roes: hoop, scrap-heap; kleur, rust colour; kleurig, (-e), rust-coloured, foxy; laag, patina; oplosmiddel, rust solvent; rooi, rust-red; terig, (-e), rusty; $\sim$ terigheid, rustiness; vlek, rust stain; vry, rust-proof, stainless; werend, (-e), anti-rust, anti-corrosion, rust-proof.

Both members of the homonym paradigm roes have been included as lemmata. The lexical item represented by the second lemma roes does not function as a stem in complex lexical items and consequently the article of this lemma has no 
niche attached to it. Contrary to this, the lexical item represented by the first lemma roes frequently occurs as first stem of complex lexical items. For spacesaving reasons the lexicographer wants to cluster these complex forms into a single textblock. Ideally a procedure of first level nesting would have attached this cluster to the article of the first lemma roes. This is prevented by adherence to a strict alphabetical ordering, and consequently procedures of remote niching and multiple niching have to be performed.

Lemmata representing homonyms are clearly identified to assist users in their endeavour to access the article of the proper source-language item. The application of multiple niching often impedes a clear and unambiguous access to the correct source-language form because the lemma part in lemma-external niche entrance cannot be linked with the appropriate main lemma without venturing into the rest of the niche. On the other hand, the consistent application of a strict alphabetical ordering does function as a prominent guideline for the user on the search route towards the needed source-language form.

\section{Semantically motivated multiple niching}

The GW adheres to a strict alphabetical ordering and this results in multiple niching. As already indicated, the strict alphabetical ordering leaves the article(s) representing the non-final member(s) of a homonym paradigm stranded when niches need to be attached to existing articles. A consistent adherence to the strict alphabetical principle should not allow semantic reasons to influence the ordering of lemmata in remote niches. The following example gives evidence to the contrary:

(23) kant $^{1}$, (s) lace; GEKLOSTE , bobbin lace; NAGEMAAKTE , imitation lace; met $\sim$ VERSIER, trim with lace.

kant $^{2}$, (-e), side, edge, brink, border, margin; limb (of a fold); flank (of army); face; hand; ...

kant'aantekening, marginal note; gloss.

kantari'de, (-s), Spanish fly, cantharides.

kant: tussensetsel, lace insertion; verkoopster, lace woman; verkoper, lace man.

kant: voorspeler, wing forward, flanker; vyl, cant, barette-file.

kant: werk, lace-work, lace; werker, lace-maker; lace man; werkster, (female) lace-maker; $\sim$ winkel, lace shop.

In this partial article stretch, incompletely presented here, the two lemmata kant represent two homonyms. The remote niches indicate an interesting aspect of the clustering of lemmata. The first and the third remote niche both contain lemmata which relate semantically to the first lemma kant whereas the lemmata in the second remote niche relate to the second lemma kant. If semantic reasons had not played a role these three niches could have been clustered into one 
textblock:

kant: tussensetsel, lace insertion; verkoopster, lace woman; verkoper, lace man; voorspeler, wing forward, flanker; vyl, cant, barette-file; werk, lace-work, lace; werker, lace-maker; lace man; werkster, (female) lacemaker; winkel, lace shop.

The consistent application of a system like the one used in the GW can assist the user to access the needed data in a predictable way. An inconsistent application leads to user-frustration because it defies the important lexicographic criterion of predictability, cf. the following example:

(25) heel ${ }^{1},(w)$ (ge-), heal, cure; granulate (wound).

heel $^{2}$, (w) (ge-), receive (stolen goods).

heel $^{3}$, (b) (hele), whole, entire, complete, unbroken, undamaged; sound; ...

$\cdots$

heel: konfyt, conserve; whole preserve; koring, whole wheat; krag, healing (curative) power; krag'tig, (-e), healing, curative; kunde, surgery; kun'dig, (-e), surgical; kun'dige, (-s), surgeon; kuns, art of healing; $\sim$ maak, (-ge-), mend; maker, (-s), mender.

The niche contains lemmata which relate to the first lemma heel, e.g. heelkrag, heelkragtig and heelkuns, whereas others relate to the second, e.g. heelkonfyt and heelkoring. Such a mixed niche, and this dictionary contains quite a number of them, diminishes the potential success of the target user to gain rapid access to the desired lemma sign. The consistent application of a well-explained system is necessary to ensure the success of a dictionary as an authoritative reference source.

\section{Heterogeneous niching}

Due to its strong adherence to a strict alphabetical ordering, the application of niching can lead users astray when unrelated words are forced into a single niche, cf. the following example from the Reader's Digest Afrikaans-Engelse Woordeboek / English-Afrikaans Dictionary:

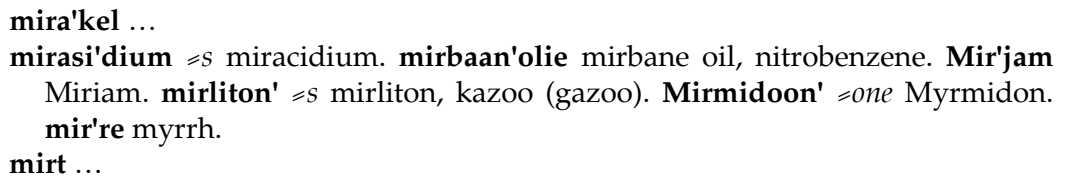

The lemma mirasidium is positioned in the default vertical ordering of the macrostructure. It is preceded by the vertically ordered main lemma mirakel. On macrostructural level, the lemma mirasidium is followed by the lemmata mir- 
baanolie, Mirjam, mirliton, Mirmidoon and mirre. These lemmata display no semantic relations with the lemma mirasidium, neither are they complex words with mirasidium as one of the components. However, the lexicographer has opted to order them in a sinuous lemma file, resembling a niche with mirasidium in the apparent niche entrance position. This sinuous file is followed by mirt, the next vertically ordered lemma.

A typical application of single niching leads to the clustering of lemmata with a mutual first component. This can be regarded as the default type of single niching. The occurrence of a mutual component allows the phasing out to the left of that lemma part. Due to the presence of a mutual component in all the complex forms clustered into the niche, this can be regarded as homogeneous niching. In the given article cluster from the Reader's Digest Afrikaans-Engelse Woordeboek / English-Afrikaans Dictionary, the niched lemmata cannot participate in a process of phasing out to the left because not all of them are complex words and they have no mutual morpheme. This can be regarded as an example of heterogeneous niching.

To the user heterogeneous niching and the consequential horizontal ordering of the lemmata mirbaanolie, Mirjam, mirliton, Mirmidoon and mirre could be extremely confusing. When looking for a specific lemma, say mirliton, the user will not see the vertically ordered lemma mirasidium as a guiding element leading him to the needed lemma. Being familiar with the way in which single homogeneous niching is done in this dictionary, the user will interpret the vertically ordered textblocks

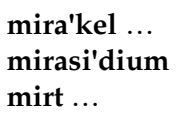

as an indication that mirliton has not been included in the macrostructure of this dictionary.

Unless the system of heterogeneous niching is explained comprehensively in the users' guidelines text, the application of such a niching procedure will be an impediment in the outer access structure of a dictionary. Procedures of textual condensation which cluster different dictionary articles into a single textblock should limit the participating lemmata to complex items which can be the target of a process of phasing out to the left due to the repetitive occurrence of a mutual morpheme in all the lemmata.

\section{In conclusion}

Niching is a lexicographic procedure which can help the lexicographer to render a more condensed macrostructure. The space-saving motivation for niching may never be at the cost of the users in their attempt to gain access to the data presented in the dictionary. Multiple niching can be regarded as a more complex form of textual condensation and it increases the level of difficulty of dic- 
tionary-consultation procedures. This is especially true of procedures of exclusively remote multiple niching and multiple niching where the interrupting textblocks do not have main lemmata which are semantically related to the basis lemma or the sublemmata. Where multiple niching is not applied in a consistent way, e.g. where a basis lemma represents a member of a homonym paradigm and the underlying homonymy is not maintained in the niches, users struggle to access the articles from which they need to retrieve information. This is also the case where heterogeneous niching and hybrid niching procedures prevail.

Lexicographers should continue to evaluate the contribution of different niching procedures. A more general use of a more diverse presentation of article clustering which includes the use of procedures of first level nesting should also be investigated.

\section{Endnotes}

1. In this article, the term textual condensation is used to include both Textverdichtung and Textkomprimierung (cf. Wiegand 1998: 31).

2. In the electronic version of this dictionary, the textual condensation has been decreased with the niched lemmata presented in their full form.

3. It is important to distinguish these pre- and post-hyphenated entries from what Gouws (1989: 215) calls pre- and post-hyphenated lemmata. A pre- or post-hyphenated lemma is a main lemma presented in the vertical ordering of lemmata to introduce a stem or affix as treatment unit. Pre- and post-hyphenated entries, as used in this article, refer to lemma parts and partial lemmata participating in a procedure of lemma clustering to present sublemmata contained in a niche or a nest.

\section{Bibliography}

\section{Dictionaries}

Bosman, D.B. et al. (Eds.). 19848. Tweetalige Woordeboek / Bilingual Dictionary. Cape Town: Tafelberg. De Villiers, M. et al. (Eds.). 19887. Nasionale Woordeboek. Cape Town: Nasou.

Du Plessis, Madeleine. 1999. New Words / Nuwe Woorde. Cape Town: Pharos.

Eksteen, L.C. et al. (Eds.). 199714. Groot Woordeboek / Major Dictionary. Cape Town: Pharos.

Eksteen, L.C. et al. (Eds.). $1992^{\circ}$. Verklarende Afrikaanse Woordeboek. Pretoria: J.L. van Schaik.

Grobbelaar, P. (Ed.). 1987. Reader's Digest Afrikaans-Engelse Woordeboek / English-Afrikaans Dictionary. Cape Town: Readers' Digest Association South Africa.

Kempcke, G. et al. (Eds.). 2000. De Gruyter Wörterbuch Deutsch als Fremdsprache. Berlin: Walter de Gruyter.

Odendal, F.F. and R.H. Gouws (Eds.). 1998. Elektroniese Verklarende Handwoordeboek van die Afrikaanse Taal. Midrand: Perskor. 


\section{Other literature}

Bergenholtz, H. 1990. Lexikographische Instruktionen für ein zweisprachiges Wörterbuch. Zeitschrift für Phonetik, Sprachwissenschaft und Kommunikationsforschung 43: 19-37.

Bergenholtz, H., S. Tarp and H.E. Wiegand. 1999. Datendistributionsstrukturen, Makro- und Mikrostrukturen in neueren Fachwörterbüchern. Hoffman, L., H. Kalverkämper and H.E. Wiegand (Eds.). Fachsprachen. Ein internationales Handbuch zur Fachsprachenforschung und Terminologiewissenschaft/Languages for Special Purposes. An International Handbook of Special-Language and Terminology Research: 1762-1832. Berlin: De Gruyter.

Gouws, R.H. 1989. Leksikografie. Cape Town: Academica.

Gouws, R.H. 1991. Toward a Lexicon-based Lexicography. Dictionaries 13: 75-90.

Gouws, R.H. 2001. The Use of an Improved Access Structure in Dictionaries. Lexikos 11: 101-111.

Hausmann, F.J. and H.E. Wiegand. 1989. Component Parts and Structures of General Monolingual Dictionaries: A Survey. Hausmann, F.J. et al. (Eds.). 1989-1991: 328-360.

Hausmann, F.J. et al. (Eds.). 1989-1991. Wörterbücher. Ein internationales Handbuch zur Lexikographie/ Dictionaries. An International Encyclopedia of Lexicography /Dictionnaires. Encyclopédie internationale de lexicographie. Berlin: De Gruyter.

Louw, P.A. and R.H. Gouws. 1996. Lemmatiese en nielemmatiese adressering in Afrikaanse vertalende woordeboeke. S.A. Tydskrif vir Taalkunde 14(3): 92-100.

Stark, M. 2001. Die toegangstruktuur in verklarende aanleerderwoordeboeke. Unpublished M.A. thesis. Stellenbosch: University of Stellenbosch.

Wiegand, H.E. 1989. Aspekte der Makrostruktur im allgemeinen einsprachigen Wörterbuch: Alphabetische Anordnungsformen und ihre Probleme. Hausmann, F.J. et al. (Eds.). 19891991: 371-409.

Wiegand, H.E. 1998. Lexikographische Textverdichtung. Entwurf zu einer vollständigen Konzeption. Zettersten, A., V.H. Pedersen and J.E. Mogensen (Eds.). 1998. Symposium on Lexicography VIII: 1-35. Tübingen: Max Niemeyer.

Wiegand, H.E. 2002. Über textuelle Strukturen der Wörterbuchartikel und Artikelnischen im "de Gruyter Wörterbuch Deutsch als Fremdsprache". Zugleich ein Beitrag zur Weiterentwicklung einer Theorie der Wörterbuchform. Wiegand, H.E. (Ed.). 2002. Perspektiven der pädagogischen Lexikographie des Deutschen II: 497-595. Tübingen: Max Niemeyer.

Wolski, Werner. 1989. Das Lemma und die verschiedenen Lemmatypen. Hausmann, F.J. et al. (Eds.). 1989-1991: 360-371.

Wolski, Werner. 1989a. Formen der Textverdichtung im allgemeinen einsprachigen Wörterbuch. Hausmann, F.J. et al. (Eds.). 1989-1991: 956-967. 